domestic animals and cultivated plants (and of man himself) is to some extent controllable, because we can by selection influence the variability of later generations; according to De Vries, evolution is beyond our control except as we discover and isolate variations. Thus does Prof. Castle contrast the two sets of views, which "remind us somewhat of the theological ideas of free-will and predestination respectively." But which view is right?

The evidence from palæontology, geographical distribution, and classification tends on the whole in favour of the Darwinian view that " evolution as an age-long process has been gradual and progressive, not abrupt and unguided," but the evidence from experimental breeding leans to either side. The mutationists hold that selection "can do nothing but isolate variations which may sporadically put in an appearance or which may by hybridisation be brought together into new combinations." The selectionists, with whom Prof. Castle ranks himself, maintain that selection "can accomplish more than the mere isolation of variations, because it can, by a series of selections, influence further variability." How is one to decide?

Prof. Castle considers carefully the attempts that have been made to generalise Johannsen's brilliant discovery of the principle of "pure lines," and shows that this is not warranted. In the case of certain characters in guinea-pigs he has himself found that a ne plus ultra is reached which cannot be changed by selection in an inbred race. "Thus a very dark form of Himalayan albino, after a certain amount of improvement by selection, could not be further darkened to any appreciable extent." On the other hand, certain characters of guinea-pigs, rabbits, and rats have been found to respond readily to selection in a particular direction. Prof. Castle's experiment with hooded rats "selected simultaneously in plus and minus directions has produced one race which is black all over except a white patch of variable size underneath, and another race which is white all over except for the top of the head and the back of the neck, which are black. The races do not overlap at all, and have not done so for many generations, though they still continue to diverge from each other as a result of continued selection."

It comes to this, that divergent conclusions are in part due to the data utilised.

"A study of albinism alone would lead one to believe in the fixity and constancy of Mendelian genes and the impossibility of modifying them by selection." But "in the case of such characters as white spotting in mammals, it is evident that a change in the mean of the character in a particular direction in consequence of selection actually displaces in the direction of selection the centre of gravity of variation, so that in a very true sense selection makes possible further variation in that same direction."

Selection cannot start new lines of variation, but it can continue and extend variation already initiated.

$$
\text { NO. } 25 \mathrm{II} \text {, VOL. [OO] }
$$

\section{THE FUTURE OF THE TRADE IN COLONIAL RAW MATERIALS.}

$\mathrm{T}$ is now well known that before the war large quantities of raw materials produced in the British Colonies found their way in the first instance to Germany, where they were converted into manufactured products, of which considerable quantities were then exported from Germany to this country and other parts of the Empire. Most people are now of opinion that this indirect method of trading should not be resumed after the war, and that these intermediate processes of manufacture should be carried on in this country, or at least within the Empire. It has also become clear, especially in the last few months, that immediately after the war there will be great competition among all the manufacturing countries for supplies of raw materials, and probably most people in the Allied countries, who realise that the Allies effectively control the bulk of the world's supplies of such materials, are of opinion that the Allies should utilise this advantage to meet their own requirements first.

There can be little doubt as to the trend of public opinion on these points, but it is not at all clear what action, if any, is being taken to give effect to it, except in the one case of West African oil-seeds, which was investigated by a special committee appointed by the Colonial Office in 1915. That committee recommended the imposition of an export duty on palm kernels exported from British West Africa to be crushed in countries outside the Empire, and this recommendation was adopted by the Secretary of State for the Colonies, with the result that the palm-kernel crushing industry established in this country since the war is likely to remain here in future. The publication of the results of the British committee's investigations has apparently stimulated the Colonial Institute at Marseilles into conducting similar inquiries into the sources of supply of the raw materials which form the basis of two of the chief industries carried on in Marseilles, namely, oil-seeds and cereals.

Committees have been appointed by the Marseilles Colonial Institute to investigate these two groups of raw materials, and the Oil-seeds Committee has already published two special bulletins. The first of these contains the report (in French) of the British West African Oil-seeds Committee, and the second gives a résumé of some of the evidence taken by that committee, a translation of a portion of the Imperial Institute monograph on oil-seeds and feeding-cakes (Murray, I9r5), and some preliminary information regarding the work of the French committee. The latter is first taking up questions connected with the trade in ground nuts, the most important oil-seed crushed in Marseilles; and the bulletin contains evidence for and against the decortication of ground nuts before shipment, a matter of first-rate importance in connection with the ground-nut trade of India. Hitherto, it has been held that ground-nut oil of edible quality cannot 
be made from ground nuts shelled in the country of production and exported in the form of kernels, the argument being that the oil in such kernels must always contain too much free fatty acid. It is clear from the French bulletin, however, that lack of tonnage, if nothing else, is now forcing French oil-seed crushers to reconsider this question and to find means of importing ground-nut kernels in good condition.

In a recent number (No. 86 of I9r7) of L'Expansion Coloniale M. Emile Baillaud, to whose activity the Marseilles Colonial Institute owes much of its prestige in France, discusses the problems which these French committees on cereals and oil-seeds will take into consideration. From this it appears that the committees are faced with much the same problems as those mentioned in the first paragraph of this article, viz. that French, like British, manufacturers have not been able to take up new oil-seeds, but have largely left the initiative in such matters to Germany, and that they have not utilised and developed sources of supply in their own colonies. It will be the chief object of the committees to ascertain how this state of things can be remedied. It is interesting in this connection to note that M. Baillaud has a proper appreciation of the necessity for technical investigations, and suggests that the Committee on Oilseeds will require to initiate investigations similar to those carried on for some years past on the oil-palm by the Imperial Institute in this country in co-operation with the Departments of Agriculture in British West Africa.

\section{NOTES.}

As an outcome of the .Departmental Committee on the Welfare of the Blind, which recently issued an excellent report, the President of the Local Government Board (Mr. W. Hayes Fisher) has appointed a Committee to advise the department on matters relating to the care and supervision of the blind. The selection of members appears to have been made with discretion, except that, as pointed out by "Ophthalmic Surgeon" in a letter to the Times of December 8, there is no medical man or ophthalmic surgeon upon the Committee. The original Committee had an ophthalmic surgeon among its number, and applied to the Royal Society of Medicine for assistance in its deliberations. A Sub-Committee of the Ophthalmological Section was appointed, and devoted much time and trouble to the subject. The report shows that it afforded very material help. Mr. Hayes Fisher, writing to the Times of December II, excuses himself for the absence of any medical representation on the Advisory Committee by saying that "nine-tenths of the Committee's time will be taken up with the consideration of administrative problems," and that "under existing circumstances it would not be right to make a further demand upon the time of any of our eminent ophthalmic specialists, who are already so fully occupied." The courteous terms in which this letter is couched will doubtless be appreciated by the Royal Society of Medicine and the medical profession generally, but they do not succeed in masking the characteristic official attitude. Ophthalmic surgeons themselves are the best judges of the time which they have at their disposal, and the ordinary amenities of NO. 25 II, VOL. IOO] social life should have suggested that they at least should be consulted and offered the opportunity of giving their assistance when it is proposed to put their recommendations into action.

THE project, which has been in abeyance for some considerable time, for a ship canal across the Scottish isthmus lying between the Firth of Forth and the Firth of Clyde has lately been revived, partly in consequence of the direction of military opinion towards the strategical value of such a waterway in time of war, and partly also on account of the substantial commercial advantages which would accrue generally. A question on the subject was recently put in the House of Commons, and Dr. Addison, in reply, stated that the matter was under the consideration of the Department of Reconstruction in view of the opening afforded for the utilisation of the labour of demobilised men for the execution of the undertaking. We observe, in the issue of The Engineer of November 30 , an interesting account of the inception and development of the underlying idea, which was promulgated, in the first instance, so far back as the year 1724 by Daniel Defoe. At present there are two schemes which have been elaborated. The first consists in linking up the rivers Forth and Clyde by the most direct route through the Kelvin valley. The second route, avoiding the congested district of the Upper Clyde, lies along the Forth valley, leaving the river chantiel near Alloa and ultimately reaching Loch Lomond by means of Endrick Water. A short auxiliary connection between Loch Lomond and Loch Long at Arrochar would then complete the passage to the sea. The broad difference between the two routes is that the Loch Lomond route would be at the loch level, while the direct route would be at the level of high water of spring tides. Exigencies of space forbid us to attempt even a summary of the relative advantages and difficulties of the rival schemes, each of which has its convinced supporters.

We regret to learn that Dr. A. M. W. Downing, formerly superintendent of the "Nautical Almanac," died suddently on Saturday, December 8, at sixty-seven years of age.

LADy Roberts's Field Glass Fund, which has now issued 30,000 instruments to the Army, has no funds beyond the sum necessary for returning the glasses to their owners when this is desired. The main expense is that of repairing the glasses which come back for re-issue. An appeal is made for the sum of roool. to meet the repairing bills, and the need justifies the request. The address for sending contributions (also any field-glasses and telescopes that can still be spared) is the Manager, Lady Roberts's Field Glass Fund, 64 Victoria Street, S.W.r.

The Executive Committee of the Automobile Association has decided to offer a prize of Ioool. for the best invention which will enable coal-gas to be used with advantage as a propellant of motor-cars and motor-cycles. Communications relating to this subject should be addressed to the Secretary, Automobile Association and Motor Union, Fanum House, Whitcomb Street, W.C.2, and marked "Coal Gas."

IT was announced at the Linnean Society of London on November 29 that a new Linnean Society has been established recently in Sweden as "Svenska LinnéSällskapet," intended as a means for spreading information about Sweden's greatest naturalist, Carl von Linné ( $1707-78)$. The society purposes to do this by publication of works by Linné and his pupils; to throw 